\title{
Dirty droughts causing loss and damage in Northern Burkina Faso
}

\section{Seydou Traore*}

\author{
African Climate Policy Center (ACPC), \\ United Nations Economic Commission for Africa (UNECA), \\ P.O. Box 3001, Addis Ababa, Ethiopia \\ and \\ Department of Biological and Agricultural Engineering, \\ Texas A\&M University, \\ 207B Scoates Hall 2117, \\ Tx 77843 College Station, USA \\ E-mail: se73traore@gmail.com \\ *Corresponding author

\section{Tom Owiyo} \\ African Climate Policy Center (ACPC), \\ United Nations Economic Commission for Africa (UNECA), \\ P.O. Box 3001, Addis Ababa, Ethiopia \\ E-mail: towiyo@uneca.org
}

\begin{abstract}
Extreme droughts in the northern part of Burkina Faso are locally referred to as tundi, meaning 'dirty weather', because they severely disrupt people's livelihoods in the area. This article investigates the loss and damage from the tundi droughts that occurred in 2004 and 2010 in the Sahel Region. The study conducted field survey among households in ten villages. We found that people's reliance on transhumance has been decreasing over the last decades due to the lack of good pastures, competition over natural resources and corollary conflicts. Whereas transhumance was an effective way to deal with droughts and seasonality, decreased mobility and increased interdependence between cattle and crop production has made people more vulnerable in the event of extreme droughts. Evidences from the survey results show that the vast majority of the respondents experienced negative effects of recent tundi droughts on crops (96\%) and livestock (87\%). It is also found that such extreme droughts tend to have a cascading impact; they first cause a lack of water affecting seedling and crop yields, which then affects the availability of food for people and feed for livestock. This, in turn, further limits their capacity to cope with future droughts.
\end{abstract}

Keywords: loss and damage; climate change; dirty drought; cascading impacts; crop and livestock; erosive coping; Burkina Faso; Sahel.

Reference to this paper should be made as follows: Traore, S. and Owiyo, T. (2013) 'Dirty droughts causing loss and damage in Northern Burkina Faso', Int. J. Global Warming, Vol. 5, No. 4, pp.498-513. 


\begin{abstract}
Biographical notes: Traore Seydou has currently joined a Fulbright Postdoctoral Visiting Scholar Programme at the Texas A\&M University in USA. His current research work in Texas A\&M University covers applied irrigation extension and remote sensing application in water resources management for adaptation to climate change. Previously, he worked as a Professional Research Fellow for the African Climate Policy Center (ACPC) at the United Nations Economic Commission for Africa (UNECA) based in Addis-Ababa, Ethiopia. He was appointed since 2001 as a Government Officer in Burkina Faso working for the Ministry of Agriculture, Hydraulic and Fisheries Resources; then as a Research Assistant of the Ministry of Research and Scientific Innovation. Traore Seydou graduated from Taiwan for his $\mathrm{PhD}$ and MSc degrees.

Tom Owiyo is currently a Senior Agriculture and Climate Policy Specialist at the African Climate Policy Center based at the United Nations Economic Commission for Africa. His research work includes climate resilience, autonomous adaptation at the community and household levels, integrated modelling of the impacts of climate change on agricultural production, and regional agricultural trade to explore how regional trade policies could enhance climate change adaptation strategies for food security.
\end{abstract}

\title{
1 Introduction
}

The 4th assessment report from the Intergovernmental Panel on Climate Change (2007) stated that global mean temperature changes of 2 to $4^{\circ} \mathrm{C}$ above 1990-2000 levels would exceed the adaptive capacity of many systems and result in a major increase of people's vulnerability. Impact of climate change beyond adaptation has come to be known as loss and damage. Warner et al. (2012) observed that climate variability and changes lead to loss and damage when the coping and adaptation measures are not effective for people, if they imply high costs, or if no measures are possibly taken at all. The Cancun Conference of the Parties (UNFCCC, 2010) recognised the need to understand and address loss and damage associated with the adverse effects of climate change, including extreme weather and slow-onset events. Loss and damage itself is a relatively new research domain and there is no standardised methodology yet, despite the strong urgency to evaluate and understand the scale of the problem and how society is coping with it. Scientists are now endeavouring to fill this knowledge gap on climate-related loss and damage. It is important to explore the loss and damage that results from climate stressors and to understand the interactions between livelihoods, adaptation and coping strategies and the negative effects on households and communities.

Africa is likely to be the continent most vulnerable to climate change. Climate change is affecting Africa more than any other continent because its economies are largely based on weather-sensitive systems and also because of its low adaptation capacity (IPCC, 2007). According to van der Geest and Dietz (2004), in drylands a weather hazard becomes a disaster when it hits vulnerable people. The Sahel region is a dryland area with 
a fragile ecosystem easily affected by climatic extremes. Several authors have postulated that in the Sahel, climate disturbance is an acute threat to crop and livestock farming (Okoruwa et al., 1996; Tschakert, 2007; Holthuijzen, 2011).

There has been extensive discussion on the causes of the Sahelian desiccation, and early theories attributed it to land degradation and desertification caused by overgrazing and inappropriate land use (Charney, 1975; Charney et al., 1977). More recently, climate variability is also considered as a major factor. Rains in the Sahel are unimodal (Traore et al., 2010) and interrupted by detrimental dry spells (van der Geest and Dietz, 2004). Milleville (1987) has indicated that early rains tend to be stormy, sporadic, and often fragmented in time, and that frequent and prolonged interruptions are common. Indeed, droughts are nothing new in the area, but the occurrence of severe droughts seems to be on the increase. According to Zorom et al. (2012) rainfall in the Sahel started to decrease in the late 1960s and the region has experienced many periods of severe drought since the 1970s. According to Giannini et al. (2008) the Sahel is affected by a shift to a drier climate that is tied to the global tropical sea surface temperature. They further stress that the origin of persistent drought in the Sahel is global in scale and external to the region. Increasing frequency of drought events due to global warming is expected to have adverse effects on crops and livestock productivity (Thornton, 2009).

Sahelian farmers are particularly vulnerable to climate change due to their high poverty levels and the fact that they live under difficult geographical and climatic conditions (Mertz et al., 2011). According to Morton and Cees (1999), recurrences of severe drought have lead to the deaths of millions of animals and directly affected millions of people whose livelihoods depend on livestock. Blench and Marriage (1999) reported that droughts in Sub-Saharan Africa led to significant humanitarian problems and land degradation, animal dispersion, and long-term impoverishment. There is a general concern that increasing climate variability will compound development progress in the Sahel region.

Despite the high sensitivity of the region, little focus has been given to understanding the nature of loss and damage occurring from drought at the level of local households. This gives us an impetus to investigate in the Sahel region for understanding the loss and damage extremes events related affecting people livelihood. So far, loss and damage to local livelihoods is poorly understood and there is a strong need for empirical assessment and analysis of loss and damage associated with drought in specific sectors such as livestock raising and agriculture, in order to inform policy and decision making. Therefore, this paper is intending to explore how severe droughts lead to loss and damage among households in the Sahel Region of northern Burkina Faso.

Burkina Faso is a semi-arid, landlocked country in western Africa. The northern part of the country falls within the Sahelian ecosystem. The country's economy is largely dependent on agriculture and livestock. Ninety percent of its active population is engaged in agriculture and livestock sectors, which accounts for $39 \%$ of gross domestic product (Belemvire et al., 2008). These sectors, however, are highly vulnerable to the impact of climate change. There is considerable historical evidence showing that extreme climatic conditions, especially droughts, have severely affected crop production (James, 2002; Ouedraogo et al., 2006; Barbier et al., 2009; Zorom et al., 2012) and have led to pastoralists to move out of their original agro-ecological zones (FAO, 2001). The local 
people in the region are now preoccupied with survival over-crop and livestock farming, as their main occupation and primarily source of livelihood are weather sensitive-based. So, without any attention for understanding loss and damage that can support further measures, impacts of extremes droughts will still be larger in scale and severe in intensity in Sahel. That is why the loss and damage was the subject of focus to understand experiences at grassroots levels in this present study.

\section{Methods}

\subsection{Research area}

The study was carried out in Sahel Region in the extreme northern part of Burkina Faso located between the 13th and 15th degree parallels north. Extending over $34,766 \mathrm{~km}^{2}$, Sahel Region comprises four provinces, namely Oudalan, Séno, Soum and Yagha as shown in Figure 1(a). Figure 1(b) presents the averaged normalised difference vegetation index (NDVI) between year 2000 and 2011, showing Sahel at northern part as the driest zone compared to the other regions of the country. Figure 2 represents the spatial distribution of the rains over the study area between 1996 and 2007 corroborated that Sahel is the driest part of the country. Table 1 gives the list of the villages selected for this study and their geographical attributes. Dori, located in the Séno province, is the administrative capital of the Sahel region. Rainfall in the study area is a crucial climatic element, varying in amount, timing and intensity. Long-term drought and erratic rains expose soils to degradation and subject them to erosion as the soils in the area have poor water retention capacity. The main staple crops in the region are millet and sorghum. Cultivation of cash crops such as groundnuts and sesame also takes place, but only at a very small scale. Livestock farming is one of main activities, dominated by goats, sheep and cattle. While the pastures of the region are considered to be the richest in Burkina Faso, they are experiencing accelerated degradation with the decrease in rainfall.

Figure 1 (a) Location of the study area (b) The averaged NDVI between 2000 and 2011 (see online version for colours)

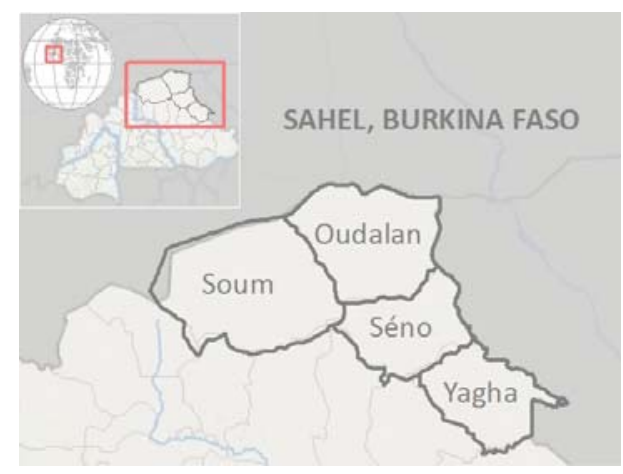

(a)

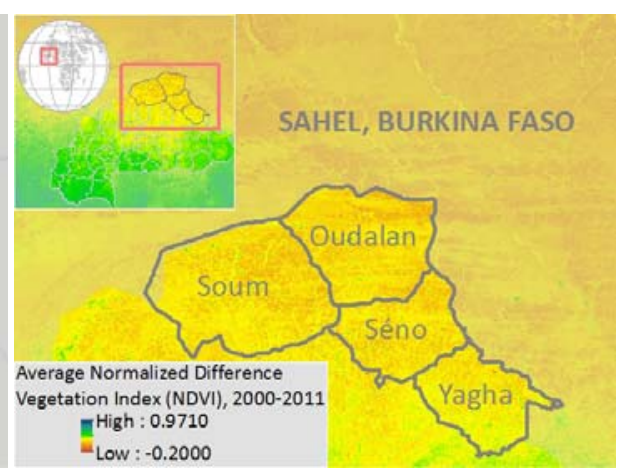

(b) 
Figure 2 Study area spatial distribution of the averaged rainfall parameter across the country (1996-2007) (a) by agro-climatic zone (b) overall rainfall (see online version for colours)

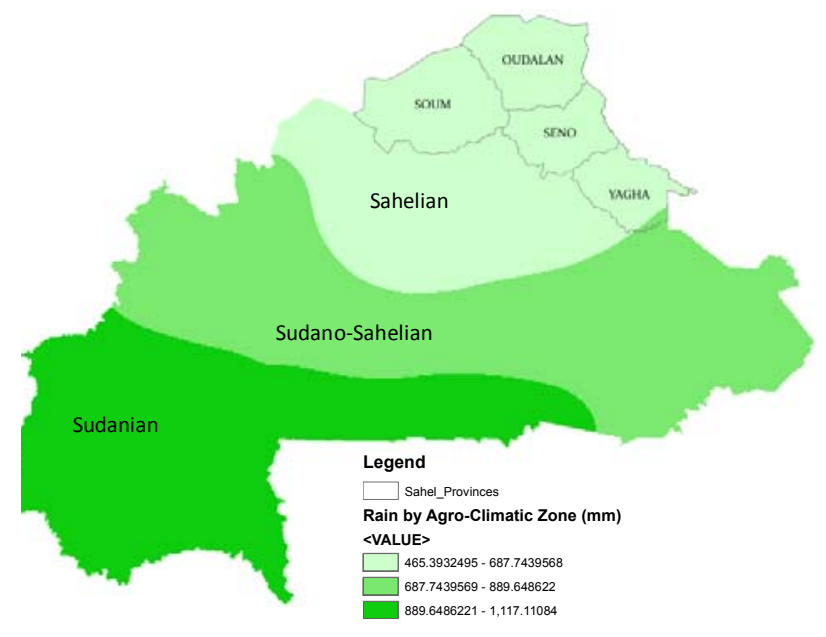

(a)

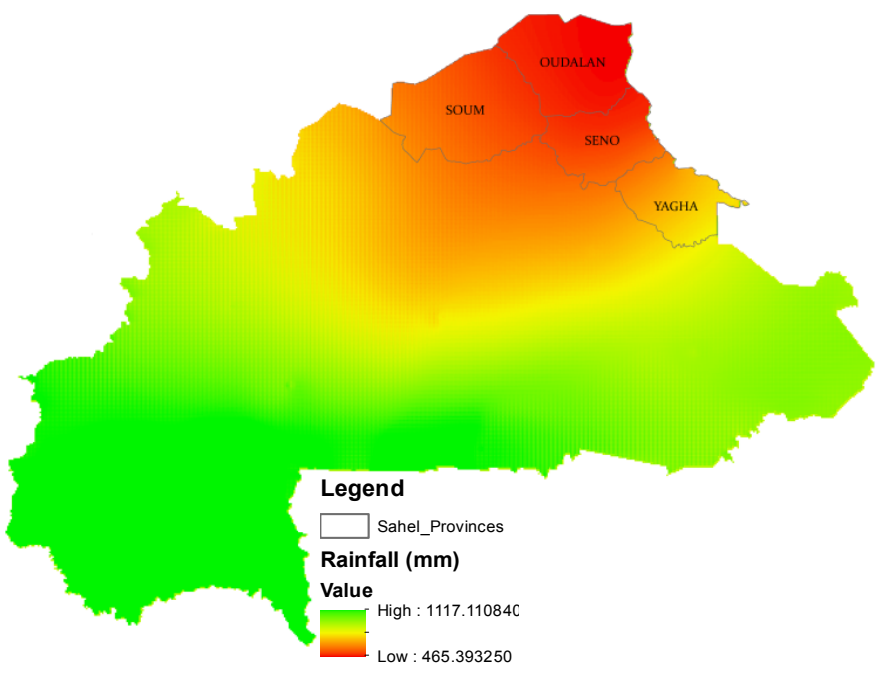

(b)

Source: Loss and Damage Case Study in Sahel, Northern Burkina Faso 
Table 1 Geography attributes of the villages surveyed in Sahel Region at Northern Burkina Faso

\begin{tabular}{|c|c|c|c|c|c|c|c|}
\hline \multirow{2}{*}{ Province } & \multirow{2}{*}{$\begin{array}{c}\text { Rural } \\
\text { commune }\end{array}$} & \multirow{2}{*}{ Village } & \multicolumn{3}{|c|}{ GPS UTM } & \multirow{2}{*}{$\begin{array}{c}\text { Total } \\
\text { households }\end{array}$} & \multirow{2}{*}{$\begin{array}{l}\text { Households } \\
\text { surveyed }\end{array}$} \\
\hline & & & Alt & Lat & Long & & \\
\hline Oudalan & Gorom-gorom & Bagawa & 227 & $1,584,840$ & 775,485 & 179 & 27 \\
\hline Oudalan & Gorom-gorom & Darkoye & 269 & $1,626,988$ & 809,103 & 256 & 37 \\
\hline Oudalan & Tin-akoff & Tin-akoff & 256 & $1,655,999$ & 804,739 & 355 & 55 \\
\hline Séno & Dori & Sambonaye & 268 & $1,565,389$ & 183,971 & 278 & 42 \\
\hline Séno & Dori & Yakouta & 279 & $1,557,008$ & 809,416 & 358 & 55 \\
\hline Séno & Gorgadji & Lelly & 291 & $1,536,441$ & 784,386 & 472 & 70 \\
\hline Soum & Arbinda & Arbinda & 320 & $1,574,089$ & 730,920 & 1,563 & 50 \\
\hline Soum & Tongomayel & Tongomayel & 295 & $1,555,625$ & 664,081 & 512 & 50 \\
\hline Yagha & Boundore & Boundore & 213 & $1,486,920$ & 273,472 & 337 & 33 \\
\hline Yagha & Titabé & Titabé & 274 & $1,323,404$ & 221,985 & 450 & 46 \\
\hline
\end{tabular}

\subsection{Sampling and data collection}

This study employed a combination of quantitative and qualitative research tools. We conducted individual household survey among 465 households from ten villages. The 465 respondents were randomly sampled by selecting $10-15 \%$ of the total households within each selected village. With the household survey we gathered information on respondents' livelihoods and vulnerability, the impacts of and coping with weather-related extreme events and adaptation to slow-onset changes, gender dimension, and the implications of different policies. In addition, we organised several focus group discussions in each surveyed village. Firstly, discussions were held with the whole communities; then separate discussions were held with men, women, young people and the elderly. We interviewed several key informants to gather experts' opinions on the subject matter such as national researchers, a university professor, governments' officers, mayors, and we also conducted a range of in-depth interviews with a select number of people who had experienced severe impacts of droughts. Desk reviews were conducted to gather ancillary data and information. These included country statistics and meteorological attributes and trends.

\section{Results}

\subsection{Livelihood characteristics}

Findings from the individual household survey show that the major livelihood activities are crop cultivation ( $96 \%$ of the respondents) and livestock keeping (93\%), as shown in Figure 3. Most respondents indicated to combine crop cultivation and livestock farming. These two sectors are rainfall dependent and hence are highly vulnerable to climate variability. Obviously the Figure 3 revealed that these two sectors are the main occupations of the households as the proportion of responses are the highest $(>90 \%)$. A 
fifth of the households engages in trade, and that only very few households engage in fishing $(2.7 \%)$ or have white colar work $(1.1 \%)$.

Figure 3 Proportion of households engaged in different livelihood activities by province in the Sahel Region at the Northern Burkina Faso(see online version for colours)

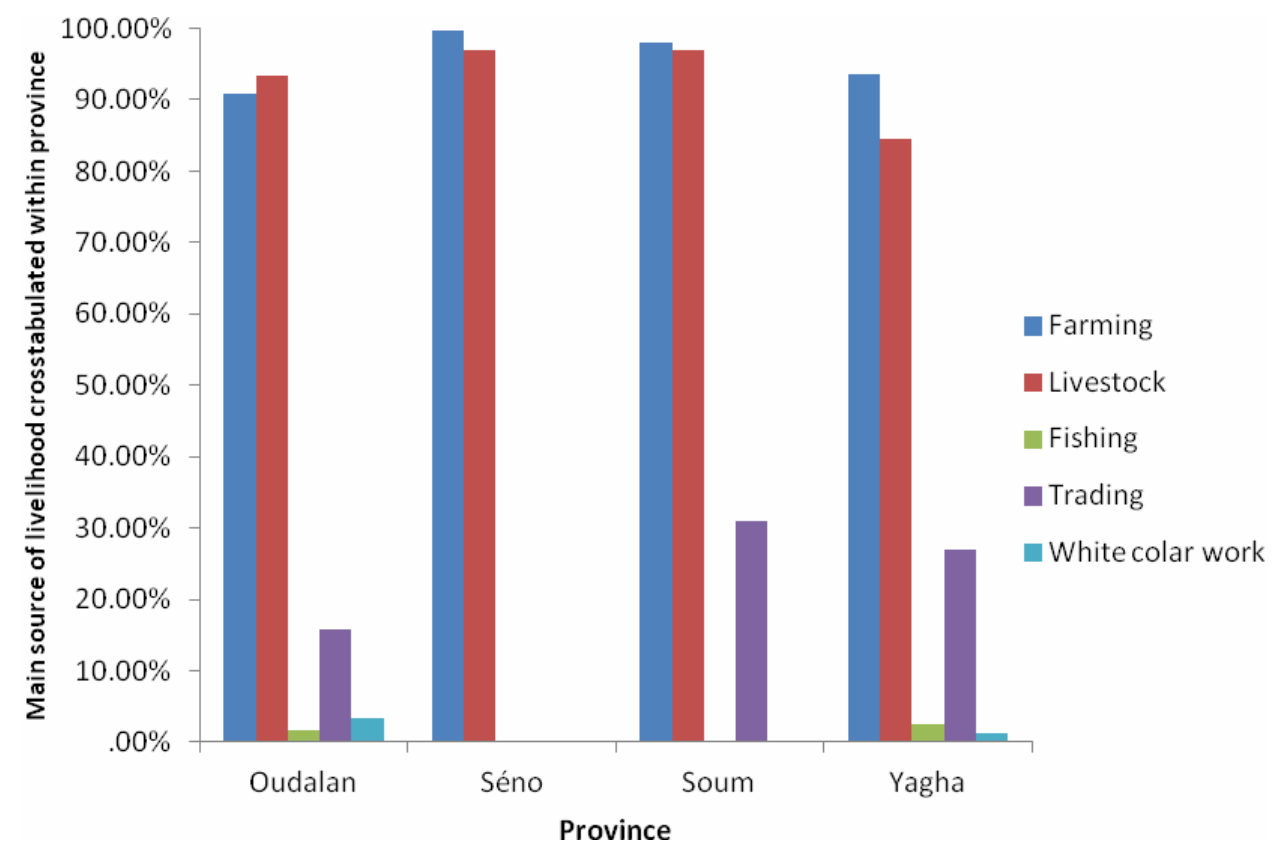

In the past, pastoralists in the study area were mobile through transhumance over relatively long distances and periods of time. We found, however, that their options to move around with cattle have decreased in the recent past, and that people have started to destock. In focus group discussions people explained that there is a general tendency to shift from purely cattle-based livelihoods towards a combination of crop production and livestock keeping. This shift is caused by a combination of factors, including decreased mobility with herds due to lack of pastures, high pressure on available natural resources, and conflicts in the region, which are often related to the use of natural resources. Former pastoralists indicated that they preferred to combine cattle raising with crop production. Reduced mobility and increased integration of crop production and livestock raising seems to have made people more vulnerable in times of extreme drought, as we will argue below.

\subsection{Characteristics of drought events}

Almost all questioned respondents (98\%) reported drought to be the main climate stressor that has negatively affected the Sahel in Northern Burkina Faso. This was confirmed by the findings from the focus group discussions. Drought is perceived by communities in Sahel as tundi weather, which literally means dirty weather in fulfudé. This term is indicative for the severe negative impacts of extreme droughts. A tundi drought is unpredictable, prolonged, has a large coverage, and is usually brought to a screeching halt by crushing spontaneous heavy rains. Interviews with key informants, and also the 
analysis of the drought index from recorded historical rainfall data, revealed that 2004 and 2010 were years of tundi drought in the recent past in the region.

Figure 4 Total annual precipitation and number of rainy days per year over the Sahel region (1960-2010) (see online version for colours)

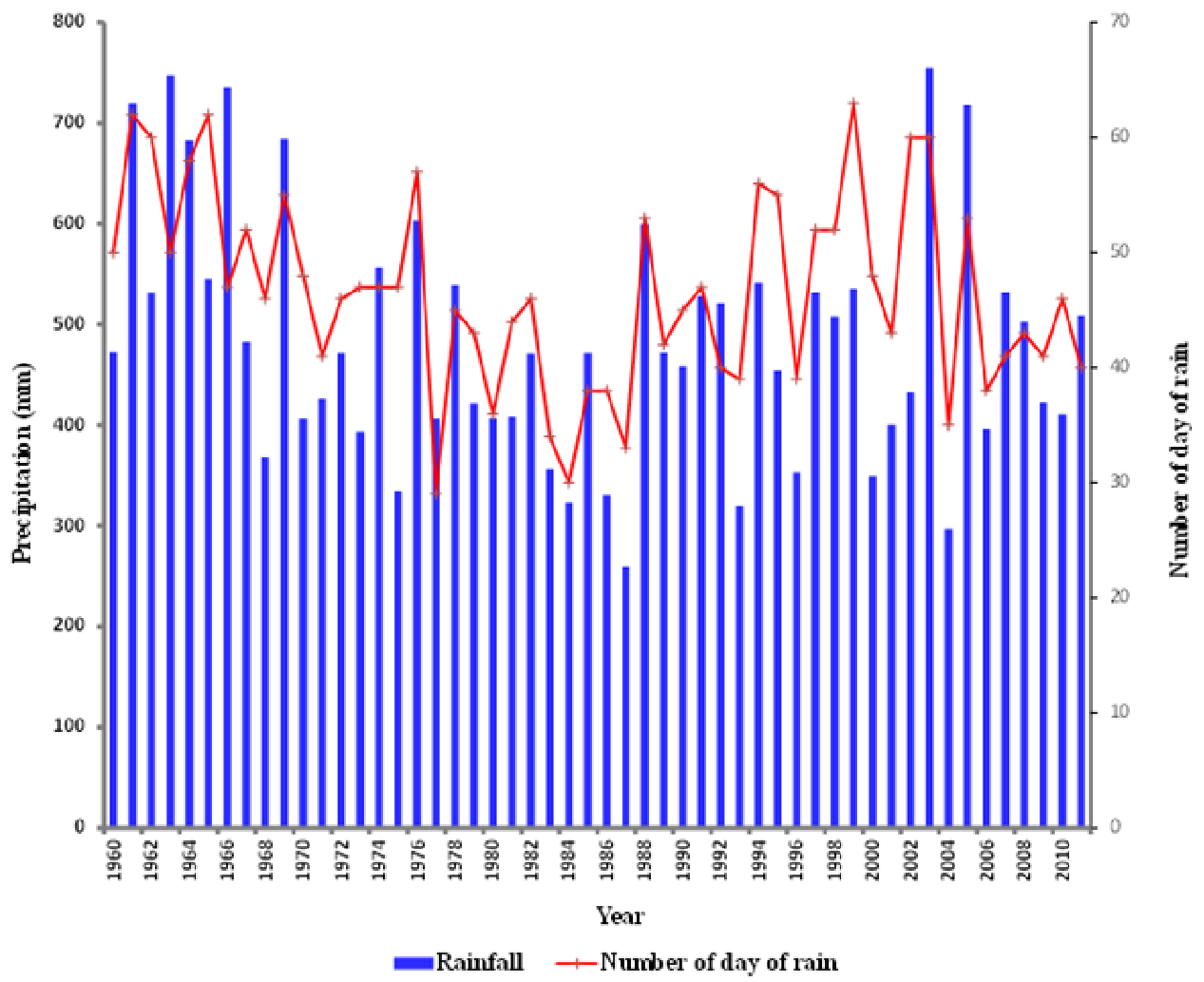

Figure 4 shows the precipitation trend and the number of days of rains between 1960 and 2011. The number of rainy days is marked by peaks and depressions revealing an unstable climate and the presence of pockets of drought. The years with the least rainy days were 1983, 1984, 1985, 1987 and 2004, varying between 33 and 38 days of rains. Likewise, the rates of precipitation fluctuate greatly and show a non-linear decrease in number of days of rainfall per year. The average precipitation is $483.78 \mathrm{~mm}$ per year, with a standard deviation of $125.64 \mathrm{~mm}$ and the inter-annual rainfall variability amounted to $25.97 \%$ between 1960 and 2010 . This high standard deviation implies a high variation of rainfall from one year to another.

\subsection{Preventive strategies}

In an attempt to minimise the impact, households reported undertaking some preventive measures before the onset of drought, and government agencies and non-government organisations (NGOs) occasionally intervened to assist communities. The main preventive measures are: 
- Mowing forage and conserving hay and fodder, which allows people to have some fodder for short periods during a drought.

- Construction of traditional on-farm rainwater reservoir (boulis) in most of the villages. These are reservoirs dug by hand that allow households to retain rainwater for use during drought periods for domestic purpose, livestock watering and small farming vegetable cultivation.

- Construction of few agro-pastoral infrastructures such as dams by the government and other organisations. These enable people to limit the negative effect of droughts and diversify their activities with fishing and vegetable production.

The results have showed that the rural communities' in the region received occasional and very limited supports from government departmental agencies as indicated by respondents. Other organisations such as NGOs and religious organisations do not remain on the sidelines of the interventions; they are sometimes presents in Sahel as reported by respondents. Most of these supports are mainly axed on food aids and do not really empower local people adaptive capability to robustly protect their production farmingbased. Exception of mowing and conservation of forages, households have seen no real measures to protect livestock as transhumance option is decreasing. These typically preventive measures are, however, not sufficient to completely cushion households from the impact of severe droughts, as we will describe in the following section.

\subsection{Impact of drought}

The majority $(92.6 \%)$ of the respondents perceived the impacts of drought on their livelihoods to be severe. This percentage evidenced the intensity and severity of several repetitive droughts that have been experienced in Sahel Region in the recent past. About merely $6.5 \%$ of the respondents said to have been affected but not severely. Of all respondents, only $0.9 \%$ reported no adverse effects of drought.

\subsubsection{Effects on crop production}

The majority (95.6\%) of the respondents who experienced drought impacts indicated that their crop production was affected (Figure 5). About $79 \%$ of respondents indicated that crop production has decreased a lot over the last ten years due to the recurrent droughts and low rainfall. Respondents particularly pointed out the crop failure and the loss of crop seeds. Due to the lack of rains, so seeds do not germinate, or seedlings die soon after germination. If possible, the farmers will then buy new seeds and start another round of planting. Women during the focus group discussion indicated that in severe dry years they sometimes re-sow up to four times. And, eventually, they may fail to produce any crop at all. The situation is compounded by the fact that seeds are expensive and the cropping season in the Sahel is very short. Therefore, even if households are able to re-sow, they may still be unable to catch up with the three to four rainy months needed for successful crop production in Sahel. Furthermore, in dry years, invasion of crops fields by locusts and granivorous birds often leads to additional crop losses. The average range of loss in crop production given by respondents is between US\$577 and US\$636 per household. 
Figure 5 Proportion of households experiencing adverse effects of drought on crops and livestock (see online version for colours)

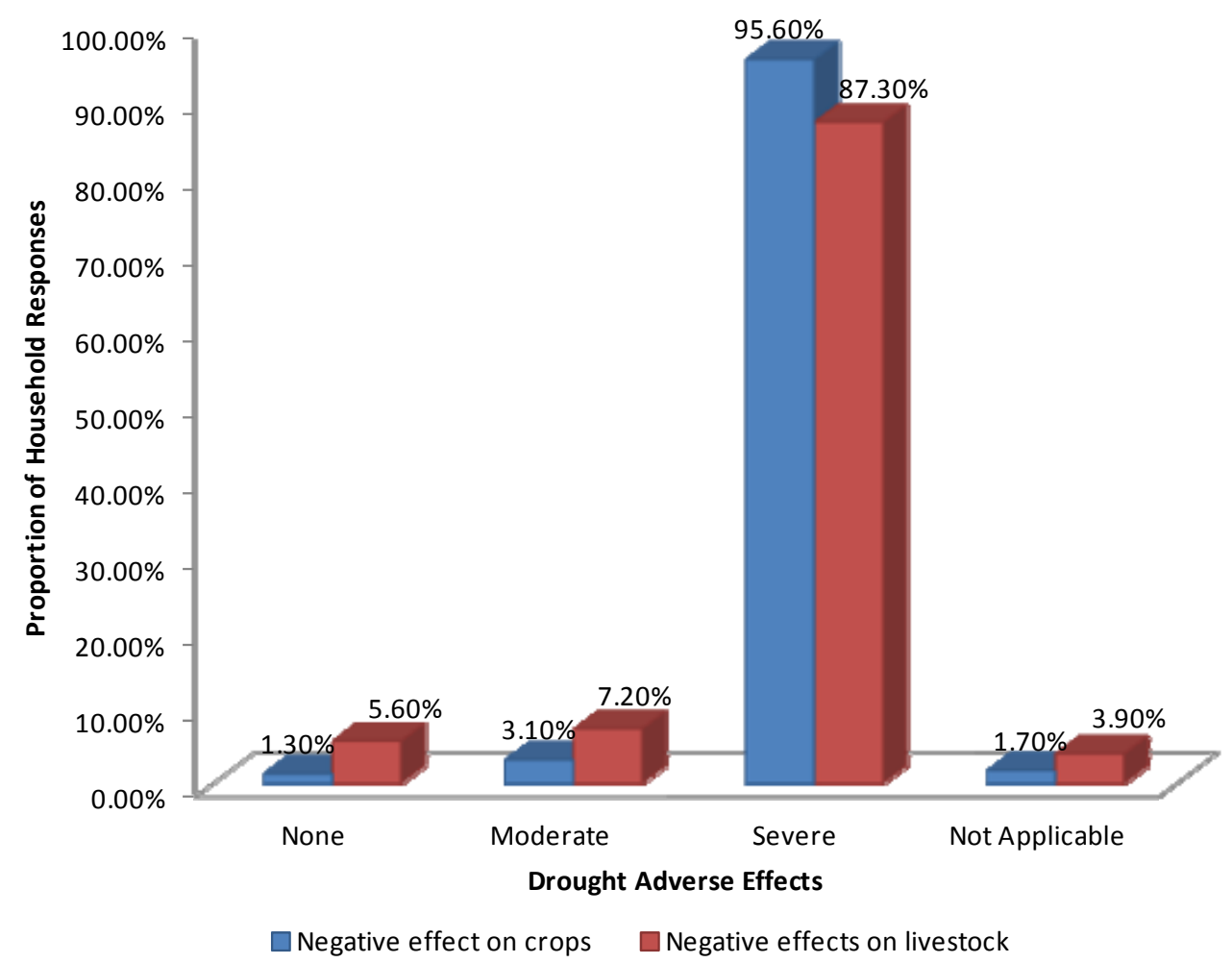

\subsubsection{Effects on livestock}

Like crop production, livestock keeping is severely affected by droughts, as reported by $87.3 \%$ of respondents (Figure 5). This is mostly because of a lack of forage and pastures (mentioned by $61.9 \%$ of the respondents) and a lack of drinking water (mentioned by $26.7 \%$ of the respondents). Respondents also noted the reduced nutritive value of pastures and the pollution of pastures by locust invasions in dry years. They argued that more frequent and longer droughts in Sahel are associated with frequent pest attacks, quite unlike in the past when pests appeared generally in years of good rainfall in the region. The lack of feed and water resources for livestock leads to reduced milk production and livestock reproduction, and $78 \%$ of the respondents in the survey indicated that their livestock production had decreased over the last ten years. Survey Respondents have revealed that the lack of feed during a period of drought increases the vulnerability of the animals to diseases. They also noted that the failure to meet animals' food and water requirements leads to weakening of animals, dietary deficiency disorders, reduced milk production and animal reproduction, development of diseases, and ultimately the death of animals. Nearly one-quarter $(24.7 \%)$ of the households reported an increase in animal mortality due to drought, with most animals dying in 2004 and 2010. Transhumance was effective before, but according to our results, it is becoming less effective in recent past decades. One of 
the pastoralists, Dicko Hamidou, said in an interview: "In year 2004 I went to transhumance during the drought period with my herd of more than 200 cattle and 122 small ruminants up to the district of Gandafabou in Oudalan province, located on the border with Mali. However, I lost most of my herd, and was left with only 50 heads." Key informant experts interviewed explained that it often takes a while for the livestock sector to recover after a severe drought. This is due to the fact that fodder seed reserves are naturally stored in the ground and their germination takes place after the early rains, drought coming soon after early rains affects the seed germination processes, and in the long term may severely impact on the natural seed bank. Little wonder, therefore, that it takes significant amounts of time to reconstitute fodder reserves after successive droughts. The respondents were asked to estimate from their own perception the costs of the losses induced by a past drought on their livestock farming. From their experiences, in year 2004, they encountered high number of animals' mortality; the cost associated to these losses was estimated between US\$1,922 and US $\$ 8,759$ per herder in the region. These values do not take into account others losses in the livestock production chain, as drought affects the livestock market as well, leading to a fall in livestock selling prices (reported by $10.1 \%$ of respondents), primarily due to market glut and the low weight of the animals.

\subsubsection{Effects on trade and food prices}

Any decline in crop production will cause a scarcity of food commodities in the market. During a drought, traders of agricultural products face a commodity shortage, leading to a surge in prices and a slowdown in business due to the low purchasing power of households. Of all respondents, $95,4 \%$ indicated that droughts lead to higher prices of food and other products. This situation often leads to further exposure of vulnerable households to more debilitating levels of poverty. There is a small group of people who are less vulnerable. The $0.9 \%$ of the households who reported no adverse effects of drought are mainly traders of exported food commodities in the village. Indeed, for this category of households, a drought situation may even increase their marginal benefit by speculating on food products.

\subsubsection{Other types of impacts}

At household level, $68.8 \%$ of the respondents reported having recurrent food availability problems and a lack of drinking water, resulting in malnutrition. To cope with food shortages, the majority of the respondents reported they had to reduce food consumption in the aftermath of drought. Low rainfall was considered as the major cause of local food shortages $(74.8 \%$ of the respondents), followed by pest attacks (17.4\%). Some respondents $(2.6 \%)$ reported health problems due to diseases caused by nutritional deficiencies. Although households in the Sahel generally do not have a vocation for fishing and fish farming, the study found that around $2.7 \%$ of the households are involved in fish farming (mainly in villages adjacent to rivers or dams) and more than half of these respondents reported that their fishing activities were severely affected in periods of drought, due to the reduced water levels and fish population. Other impacts of drought include the disappearance of woody and herbaceous species, which are sometimes used as food for human as well as for animals. 


\subsection{Coping strategies}

\subsubsection{Coping measures at the household level}

Approximately $79 \%$ of the respondents took measures to cope with the impacts of recent extreme droughts. Table 2 summarises these coping measures at the household level. Most households modified their food consumption. We considered this as a coping mechanism, but one could also argue that it is a result of the failure of other coping strategies that aim to get access to food in the aftermath of drought. The second-most common coping mechanism was the sale of properties - often animals - to generate income, used to purchase food and feed. The sale of animals is being seen as a strategic coping measure to reduce herd sizes and be able to feed the remaining. About $51 \%$ of the respondents indicated to have received sporadic support from NGOs, religious organisations and government organisations including the Ministry of Agriculture, the Social Action Department, and local government's entities. Migration is another way to deal with an extreme drought, as reported by $41.3 \%$ of the respondents. About $5 \%$ of the respondents mentioned temporary migration by the whole family, but in most of the case it is only the head of the household or one of the sons who migrates temporarily, in order to find income-earning opportunities elsewhere. Respondents in focus group discussions indicated that recent severe droughts caused the disruption of many families cohesion and a labour exodus. Generally, however, people come back to the region after the drought. Some households resorted to non-agricultural occupations such as gold mining, trade and artisanal activities. Other measures like begging, praying and relying on external supports were also reported.

Table 2 Coping strategies

\begin{tabular}{lc}
\hline Coping mechanism & Percentage of households \\
\hline Modify food consumption & 87.1 \\
Sell property & 78.7 \\
Spend less money & 72.8 \\
Received support & 50.9 \\
Migration & 41.3 \\
Earn extra income & 32.7 \\
Transhumance & 4.5 \\
Begging & 0.4 \\
\hline
\end{tabular}

Of the households who mentioned to have taken coping measures in response to recent tundi droughts, $71 \%$ indicated that these were insufficient to prevent the negative effects of the drought. The remaining $29 \%$ said that the measures were sufficient, and $13 \%$ even indicated an improvement of the situation. This later group consists primarily of households who, in response to the drought, got engaged in gold panning, which is a booming sector in Sahel region.

Approximately $21 \%$ of the respondents reported not taking any action to reduce the impacts of drought. When we further investigated the reasons for non-action, $79 \%$ of those respondents explained that their non-action was due to lack of knowledge about 
what to do. Others reasons for non-action included lack of financial resources $(16.3 \%)$ and lack of other resources $(6.1 \%)$. Some of these households (2\%) reported that they believed it was not their responsibility to take any initiative as human beings are incapable of coping with climate vagaries, which they perceived as an 'act of God'. About $5.1 \%$ of the respondents indicated that lack of technical skills was the main reason for inaction.

Figure 6 Summary of the key findings of drought-related extreme events in Sahel, Northern Burkina Faso (see online version for colours)

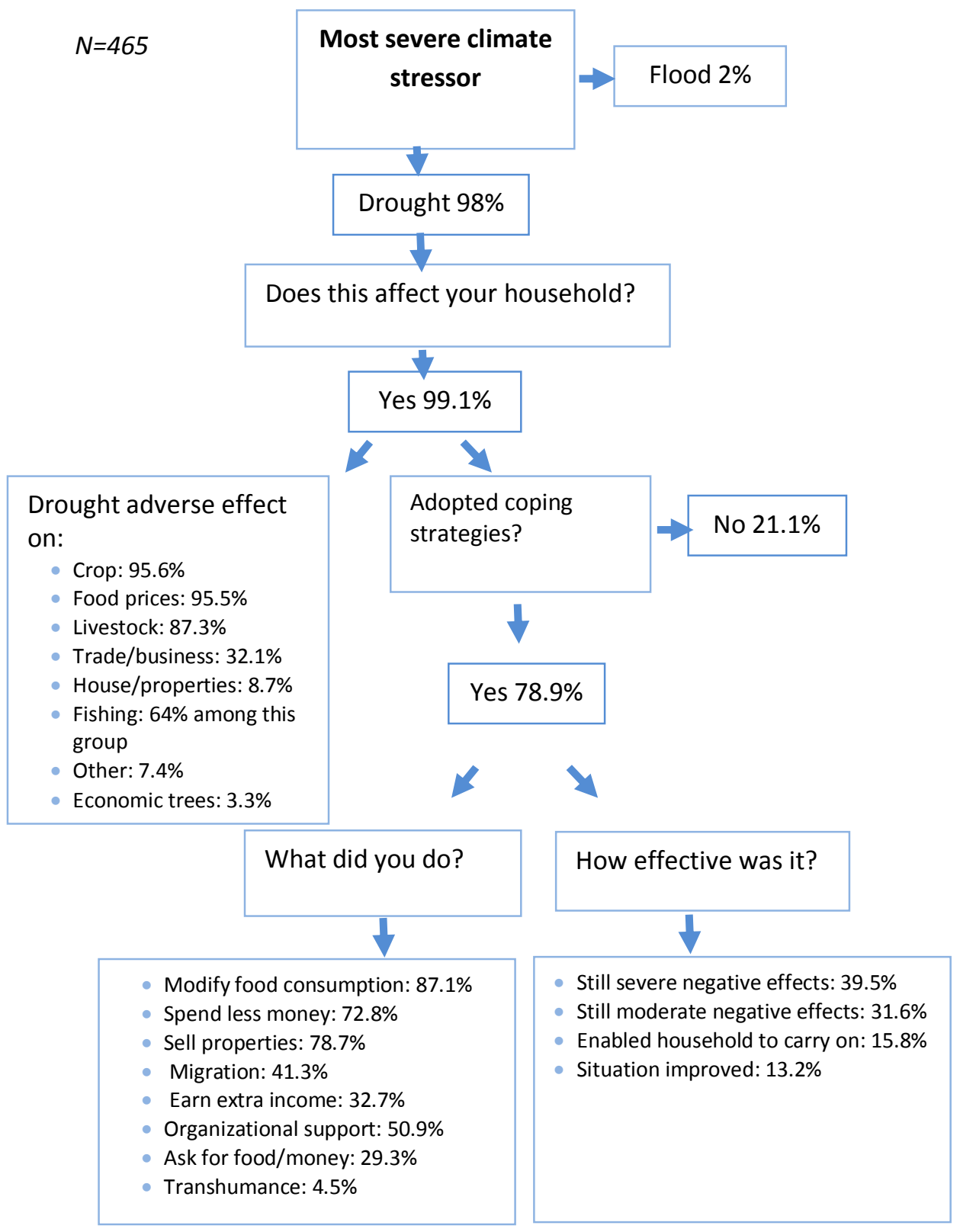




\subsection{Loss and damage}

We calculated the percentage of households that suffered loss and damage (L\&D) using the following equation (Warner and van der Geest, 2013):

$$
\mathrm{L} \& \mathrm{D}=(\mathrm{ES} * \mathrm{AH} * \mathrm{AM} * \mathrm{IDM})+((1-\mathrm{AM}) * \mathrm{ES} * \mathrm{AH})
$$

where ES stand for experienced climate stressor, AH for affected household, AM for adopted measures, and IDM for the impact despite measures. Following this equation, we found that $79.6 \%$ of the respondents experienced loss and damage. These are the households that reported adverse effects despite adopting measures to cope, and the households who were negatively affected, but did not adopt any measures in response (see also Figure 6).

\section{Discussion and conclusions}

The research area is traditionally known as a pastoral zone. At the onset of this study we therefore expected a much more significant impact of extreme droughts on people's livestock in comparison to the impact on the cultivation of crops. The results of our household survey, however, showed that most respondents indicated severe negative impacts on both livestock and crops, with even a higher percentage of respondents mentioning crop failure. A further investigation of this unexpected finding revealed an emerging trend with many pastoralists diversifying their livelihood portfolios by embracing crop cultivation. Transhumance used to be practised as a coping measure by pastoralists, who would move their cattle over long distances (even into Mali a neighbour country), in search of pastures and watering points for their livestock during times of drought. Today, however, pastoralists face decreasing possibilities to move around with large herds of cattle, partly due to conflicts over access to pastures. Respondents perceived extremes droughts in the Sahel region as the main cause of dismantling their pastures resources that increases pressure and conflict amongst communities. Decreased mobility, in its turn, decreased the adaptive capacity of pastoralists during times of drought, i.e., the possibility to move to green pastures. According to many respondents this has lead to large losses of cattle in extremely dry years over the last decade. As a consequence, full dependence on livestock was increasingly seen as making households more vulnerable. Moreover, for many pastoralists who had lost a large portion of their cattle herd, crop farming became the only option. As such, many people in the area became agro-pastoralists, with a high interdependence between crop cultivation and cattle raising, because a part of the crops and crop residues are used to feed the cattle. This trend has also been documented elsewhere (Okoruwa et al., 1996; Rasmussen, 2012). The type of livelihood diversification that is taking place in the research area helps people to survive. It may even increase livelihood security in normal years, as a farmer can control the production of cattle feed, using crop residues, crop tops and stored fodder to supplement animal feed. However, in years with an extreme drought, the interdependence of the two livelihood activities becomes a trap, as the failure of the one leads to the failure of the other. Eventually people have neither food for themselves nor feed for their cattle, and are forced to sell cattle in order to survive. As noted by Smit and Wandel (2006) vulnerability is a function of exposure and adaptive capacity. We conclude that 
people in the research area are highly vulnerable because their adaptive capacity to deal with extreme droughts is limited and is becoming lower. Tundi droughts tend to have a cascading impact, which forces people to cope in an erosive way, compromising their livelihood security. Extreme droughts first cause a lack of water affecting seedling and crop yields, which then affects the availability of food for people and feed for livestock, which eventually forces people to sell part of their livestock as a way to survive. This, in turn, further limits their capacity to cope with future droughts. The implications of these findings for policy-making are to improve the discontinuity between household and community coping strategies and government policy environment.

\section{Acknowledgements}

The authors would like to thank the National Institute of Environment and Agricultural Research (INERA) in Sahel for hosting and providing the facilities for the study. Our acknowledgement goes to the Meteorology Department of Burkina Faso for providing the weather data used in the study. The authors also thank the African Climate Policy Center of the United Nations Economic Commission for Africa for financing this study. Acknowledgement also goes to the United Nations University of Bonn for providing technical expertise and assistance during the research tool design, field work and manuscript preparation.

\section{References}

Barbier, B., Yacouba, H., Karambiri, H., Zorome, M. and Some, B. (2009) 'Human vulnerability to climate variability in the Sahel: farmers' adaptation strategies in northern Burkina Faso', Environmental Management, Vol. 43, No. 5, pp.790-803.

Belemvire, A., Maiga, A., Sawadogo, H., Savadogo, M. and Ouedraogo, S. (2008) 'Evaluation des impacts biophysiques et socio economiques des investissements dans les actions de gestion des ressources naturelles au nord du plateau central du Burkina Faso. Etude sahel Burkina Faso', Rapport de Synthèse, p.94.

Blench, R. and Marriage, Z. (1999) Drought and Livestock in Semi-arid Africa and Southwest Asia, Working Paper 117, Overseas Development Institute Portland House Stag Place London SW1E 5DP, p.138.

Charney, J., Quirk, W.J., Chow, S.H. and Kornfeld, J. (1977) 'A comparative study of the effects of albedo change on drought in semi-arid regions', Journal of the Atmospheric Sciences, Vol. 34, No. 9, pp.366-1385.

Charney, J.G. (1975) 'Dynamics of deserts and drought in the Sahel', Quarterly Journal of the Royal Meteorological Society, Vol. 101, No. 428, pp.193-202.

FAO (2001) 'Pastoralism in the new millennium, improving the livelihoods of pastoralist families and communities', FAO Animal Production and Health Paper, p150, ISBN 92-5-104673-5.

Giannini, A., Biasutti, M. and Verstraete, M.M. (2008) 'A climate model-based review of drought in the Sahel: desertification, the re-greening and climate change', Global and Planetary Change, Vol. 64, Nos. 3-4, pp.119-128.

Holthuijzen, W.A. (2011) 'Dry, hot, and brutal: climate change and desertification in the Sahel of Mali', Journal of Sustainable Development in Africa, Vol. 13, No.7, p.24, ISSN 1520-5509.

Intergovernmental Panel on Climate Change (IPCC) (2007) 'Summary for policy makers', in Climate Change 2007: Impacts, Adaptation and Vulnerability [online] http://www.ipcc.ch/pdf/assessment-report/ar4/wg2/ar4-wg2-spm.pdf. 
James, W.H. (2002) 'Realizing the potential benefits of climate prediction to agriculture: issues, approaches, challenges', Agricultural Systems, Vol. 74, pp.309-30.

Mertz, O., Mbow, C., Reenberg, A., Genesio, L., Lambin, E.F., D’haen, S., Zorom, M., Rasmussen, K., Diallo, D., Barbier, B., Moussa, I.B., Diouf, A., Nielsen, J. and Sandholt, I. (2011) 'Climate factors play a limited role for past adaptation strategies in West Africa', Atmospheric Science Letters, Vol. 12, No. 4, pp.104-108.

Milleville, P. (1987) 'Activités agro-pastorales et aléa climatique en région sahélienne', DGRSTORSTOM, p.9.

Morton, J. and de Haan, C. (1999) 'Policy options paper: community based drought management for the pastoral livestock sector in Sub-Saharan Africa', Partnership for Livestock Development and Poverty Alleviation and Sustainable Growth, $17 \mathrm{p}$.

Okoruwa, V., Jabbarht, M.A. and Akinwumi, J.A. (1996) 'Crop-livestock competition in the West African derived Savanna: application of a multi-objective programming model', Agricultural Systems, Vol. 52, No. 4, pp.439-453.

Ouedraogo, M., Somé, L. and Dembele, Y. (2006) Economic Impact Assessment of Climate Change on Agriculture in Burkina Faso: A Ricardian Approach, CEEPA Discussion Paper No. 24, Centre for Environmental Economics and Policy in Africa, University of Pretoria.

Rasmussen, L.V., Rasmussen, K., Reenberg, A. and Proud, S. (2012) 'A system dynamics approach to land use changes in agro-pastoral systems on the desert margins of Sahel', Agricultural Systems, Vol. 107, No. 1, pp.56-64.

Smit, B. and Wandel, J. (2006) 'Adaptation, adaptive capacity, and vulnerability', Global Environmental Change, Vol. 16, No. 3, pp.282-292.

Thornton, P.K., van de Steeg, J., Notenbaert A. and Herrero M. (2009) 'Review: the impacts of climate change on livestock and livestock systems in developing countries: a review of what we know and what we need to know', Agricultural Systems, Vol. 101, No. 3, pp.113-127.

Traore, S. Wang, Y.M. and Kerk, T. (2010) 'Artificial neural network for modeling the reference evapotranspiration complex process in Sudano-Sahelian zone', Agriculture Water Management Journal, Vol. 97, No. 5, pp.707-714.

Tschakert, P. (2007) 'Views from the vulnerable: understanding climatic and other stressors in the Sahel', Global Environmental Change, Vol. 17, Nos. 3-4, pp.381-396.

UNFCCC (2010) 1/CP.16. Cancun Adaptation Framework. Report of the Conference of the Parties on its Sixteenth Session, held in Cancun from 29 November to 10 December 2010 [online] https://unfccc.int/adaptation/items/5852.php.

van der Geest, K. and Dietz, T. (2004)'A literature survey about risk and vulnerability in drylands, with a focus on the Sahel', in Dietz, T., Rueben, R. and Verhagen, J. (Eds.): The Impact of Climate Change on Drylands, pp.117-146, Kluwer, Dordrecht.

Warner, K. and van der Geest, K. (2013) 'Loss and damage from climate change: local-level evidence from nine vulnerable countries', Int. J Global Warming.

Warner, K., van der Geest, K., Kreft, S., Huq, S., Kusters, K. and de Sherbinin, A. (2012) Evidence from the Frontlines of Climate Change: Loss and Damage to Communities Despite Coping and Adaptation, Loss and Damage in Vulnerable Countries Initiative, Policy Report, Report No. 9. United Nations University Institute for Environment and Human Security (UNU-EHS), Bonn.

Zorom, M., Barbier, B., Mertz, O. and Servat, E. (2012) 'Review: diversification and adaptation strategies to climate variability: a farm typology for the Sahel', Agricultural Systems [online] http://dx.doi.org/10.1016/j.agsy.2012.11.004. 